\title{
1. Reflections on the historical development of natural resource and environmental economics
}

\author{
John C. Bergstrom
}

\section{INTRODUCTION}

There are many perspectives on the historical development of natural resource and environmental economics, and what constitutes the main ingredients of the body of knowledge and associated teaching in the field. This introductory chapter, and outline of this book as a whole, represents the author's personal perspectives on these topics. ${ }^{1}$ Also, since this is a book about teaching natural resource and environmental economics, in this chapter I also attempt to highlight the academic heritage of natural resource and environmental economics including key contributors and programs. Teachers of environmental and resource economics can enhance their lectures with some history of thought story telling. This chapter, which is heavily influenced by the author's own teaching and research experience provides a brief introduction. Thus, I do not claim that this chapter covers everything and everybody that may be important components of an overview and history of natural resource and environmental economics. The interested reader should also see Spash (1999), Pearce (2002), Heal (2007), Kling et al. (2010), Lichtenberg et al. (2010), Sandmo (2015), Brown et al. (2016), and Groom and Talevi (2020) for fuller treatments from different perspectives.

Historically, natural resource economics and environmental economics developed, for the most part, as separate sub-disciplines of the general discipline of economics. However, as discussed later in this chapter, more holistic, ecological thinking about natural resource and environmental issues and problems led to somewhat of a merging of these two sub-disciplines. But I first consider the historical development of these sub-disciplines as separate fields of study and teaching. 


\section{THE “CONSERVATION MOVEMENT” AND NATURAL RESOURCE ECONOMICS}

I took my first natural resource economics class in 1979 at the University of Maryland, College Park. The instructor for the course was Dr. Ivar Strand and the textbook for the class was Ciriacy-Wantrup's classic book, Resource Conservation: Economics and Policies, first published in 1952. This classic book by Ciriacy-Wantrup contributed to the emergence of "natural resource economics" as a sub-discipline in the 1950s. This book also contains themes and concepts reflected in modern-day environmental economics which by many accounts emerged as a sub-discipline in the 1970s. Professor Ciriacy-Wantrup is also credited for starting a long history of teaching and research in natural resource and environmental economics in the Department of Agricultural Economics at the University of California, Berkeley (Brown et al., 2016).

The fact that the title of Ciriacy-Wantrup's 1952 book prominently displayed the word "conservation" reflects a longer history and concerns regarding natural resource scarcity and conservation. For many students of natural resource and environmental economics, the idea that natural resources are scarce and therefore pose limits to economic growth and human welfare is introduced and illustrated by the "Malthusian Doctrine." The main tenants of this doctrine, named after its 18 th-century originator, a classic political economist by the name of Thomas Malthus (1766-1834), are that human population growth will exceed the ability of the natural resource base (what may now be called "natural capital") to support essential life-support services such as food production (Malthus, 1798). That is, according to the Malthusian Doctrine, natural resource scarcity will ultimately lead to catastrophe.

Thomas Malthus was writing from the perspective of living in 18th-century England when it was experiencing rapid population growth that was straining this island nation's limited land base for agricultural production. One way out of the Malthusian Doctrine trap which many people from crowded European countries in the 18th and 19th centuries pursued was to emigrate to the sparsely populated, natural-resource-rich "New World" in the Americas. When newly arrived European immigrants settled in the Americas, many believed that the vast natural resources of the "New World" were inexhaustible, literally. However, eventually it became clear that rapid and extensive economic growth and development was depleting natural supplies of minerals, timber, and fish and wildlife at a rate where complete exhaustion was feasible. For example, at least until about the mid-19th century in the United States, huge flocks of millions of passenger pigeons darkened the sky and made a "thunderous noise that made it difficult for people to hear each other talking in normal conver- 
sation." In those days, it was inconceivable by most people that birds of such abundance could ever disappear, or even be depleted by a significant amount. However, by the end of the 19th century, the vast flocks were gone due to extensive hunting. The last known passenger pigeon died in the Cincinnati Zoo in 1914 (Yeoman, 2014).

The demise of the passenger pigeon and other similar examples of natural resource depletion showed people that natural resources were not inexhaustible, at least not in one place. However, in the U.S. in the 19th century, a "frontier mentality" going back to colonial days still persisted. This mentality envisioned the continued existence of new frontiers endowed with abundant resources ready for the taking including U.S. states and territories in the 19th century West and later into the 20th century the "last frontier," Alaska. The timber harvesting industry in the 19th-century U.S. illustrated the "frontier mentality" model of resource use whereby once timber resources were depleted in one region of the U.S., timber companies abandoned the cut-over land and moved on to new stands of timber in different regions of the U.S., generally moving from the Eastern U.S. to the Western U.S.

\section{Growth of Nature Appreciation}

However, not all Americans in the 19th century bought into the frontier mentality which de-emphasized the conservation of natural resources in one place. One such person was Henry David Thoreau (1817-1862). Thoreau was many things including abolitionist, author, business inventor, land surveyor, social activist, and both an early "conservationist" and "environmentalist." $\mathrm{He}$ attended Harvard College (later Harvard University) from 1833 to 1837 taking classes in rhetoric, classics, philosophy, and math \& science. His later writings reflected the general academic field of moral philosophy including a focus on nature (environmental ethics) influenced by one of his mentors, Ralph Waldo Emerson (1803-1882) whose moral/nature philosophy is reflected in his book entitled Nature.

Thoreau is probably best known, especially among students of the conservation and environmental movements in the U.S., for his book, Walden: Life in the Woods (Thoreau, 1854). ${ }^{2}$ In his writings and actions including extensive hikes in the countryside around Concord, Massachusetts, Thoreau advocated appreciation of nature for its aesthetic qualities during a time in America where nature was much more commonly viewed as a source of raw materials to fuel economic production and growth. Thus, Thoreau's writings and actions foreshadowed the concepts of non-consumptive and nonrival use values of natural resources (e.g., recreational hiking, wildlife observation) which are now core concepts in natural resource and environmental economics teaching programs. Thoreau may also have anticipated the also now-familiar concepts in natural 
resource and environmental economics, and environmental ethics, of intrinsic values and passive or non-use values including existence values when he wrote in his essay entitled "Walking": "in wildness is preservation of the world" (Thoreau, 1862).

The moral/nature philosophy of Emerson and Thoreau laid the groundwork for more scientific and practical treatises directly related to natural resource conservation starting with the very influential book by George Perkins Marsh entitled, Man and Nature: Physical Geography as Modified by Human Action, first published in 1864 (Marsh, 1864). In this book, Marsh described the relationships between environmental degradation, natural resource depletion, and the fall of ancient human civilizations in the Mediterranean. He used these examples to illustrate the reality of natural resource exhaustion (e.g., natural resources are not inexhaustible) and the negative consequences to human societies who poorly manage their natural resource base (natural capital) including over-exploitation. ${ }^{3}$

In 1869, after the publication of Marsh's book, Man and Nature, a personality well-known to almost all students in the natural resource and environmental fields of study, John Muir, traveled to the high Sierra Mountains of California helping to shepherd a flock of sheep into their summer grazing grounds. Muir described his experiences during this summer in one of his first essays, "My First Summer in the Sierra" (Muir, 1911). Much of this essay is devoted to describing the plants, animals, and landscape of the Sierra Mountains in California which he found beautiful and fascinating. He provided even more detailed descriptions of the high Sierra Mountains' natural resources and environment in the article, "The Mountains of California" published in 1894 (Muir, 1894). In this article, Muir theorized that the high Sierra valleys such as Yosemite Valley were developed through glacial actions. Leading scientists of the day scoffed at this glacier valley sculpting theory, which of course turned out to be supported by later geological studies and mainstream scientists.

John Muir's writings took on the moral-nature philosophical tones of Thoreau, and also the practical, scientific tones of George P. Marsh. The scientific nature of his writing reflects his academic training at the University of Wisconsin-Madison where he studied chemistry, geology, and botany for two years. The moral-nature philosophical nature of his writings is reminiscent of spiritual themes in the Bible (which Muir knew well) as in the following bit of prose in "My First Summer in the Sierra" describing the Sierra Mountains:

Through a meadow opening in the pine woods I see snowy peaks about the headwaters of the Merced above Yosemite. How near they seem and clear their outlines on the blue air, or rather in the blue air; for they seem to be saturated with it. How consuming strong the invitation they extend! Shall I be allowed to go to them? Night and day I pray that I may, but it seems too good to be true. Someone worthy will go, able for the Godful work, yet as far as I can I must drift about these love-monument 
mountains, glad to be a servant of the servants is so holy a wilderness. (Muir, 1911, p. 22)

The writings and actions of George P. Marsh and John Muir in the late 19th century helped to change the public's thinking with respect to natural resources and the environment in fundamental ways. This helped spark the "conservation movement" in the U.S. which began developing in earnest in the early 20th century (Albright, 1988). Both Marsh and Muir helped lead the public away from thinking that the natural resources of the New World (North America in particular) were inexhaustible, and towards thinking about the need to actively conserve natural resources for the betterment of present and future generations of people. They also helped the public, Muir especially, to think about natural resources and the environmental settings not just as sources of raw materials for economic production and growth, but also as sources of aesthetic enjoyment, recreation, and restoration of personal physical, emotional, and spiritual health. ${ }^{4}$ Such broad viewpoints on the values of nature that are commonplace to students studying natural resource and environmental economics in this day and age, were quite unconventional and ground-breaking at the turn of the 20th century.

\section{Conservation as Wise Use}

Other ground-breaking views related to natural resource conservation around the turn of the 20th century were practiced, voiced, and written about by Gifford Pinchot. Pinchot attended Yale University as an undergraduate student, graduating in 1889. He then did postgraduate studies at the French National School of Forestry. In 1892, upon the recommendation of Frederick Law Olmstead (designer of Central Park in New York City and one of the founders of American landscape architecture), Pinchot was hired by George Vanderbilt to manage the forests which were part of his 125,000-acre estate in western North Carolina near Asheville. Much of the Vanderbilt estate forest lands that Pinchot managed are now part of the Pisgah National Forest. Another part, the Biltmore House and Gardens, still owned by descendants of the George Vanderbilt family, are open to the public for viewing and guided tours.

As George Vanderbilt's private forester, Pinchot implemented professional forest management practices on a large scale for the first time in the U.S., earning the title held today by Pisgah National Forest as the "cradle of forestry" in America. Pinchot went on to become the first Chief of the U.S. Forest Service from 1905 to 1910. Pinchot's guiding principles for natural resource management and conservation are documented in his book entitled The Fight 
for Conservation and include the need for national development, reduction of waste, and working towards the common good (Pinchot, 1910).

With respect to conservation of natural resources, Pinchot described the "common good" as working to achieve the "greatest good for the greatest number of people for the longest time" (Pinchot, 1910). This philosophicalmoral basis for this principle goes back to the 18th-century English philosopher, Jeremy Bentham, who wrote, "Nature has placed mankind under the governance of two sovereign masters, pain and pleasure" (Bentham, 1789). Thus, Bentham considered "happiness" to be associated with the presence of pleasure and the absence of pain, and as early as 1776 stated as a matter of moral philosophy that "it is the greatest happiness of the greatest number that is the measure of right and wrong" (Bentham, 1776). John Stuart Mill popularized Bentham's moral philosophy of seeking and maximizing happiness individually and collectively, or utilitarianism, that is one of the foundations of modern economic theory. Of special note to students of natural resource and environmental economics, utilitarianism provides the philosophical-moral basis for using benefit-cost analysis, and by association the potential Pareto improvement criterion (see Chapter 3 in this book) to evaluate natural resource and environmental policy and management decisions and policies.

Pinchot's principles for natural resource conservation also encompass the ideas (or ideals) that natural resource conservation entails the wise use of natural resources over time for multiple purposes. Pinchot's focus on the wise use of natural resources provided some of the foundation for later theories and practices of economic conservation in the form of economic theory for optimal depletion of exhaustible, nonrenewable resources (e.g., minerals) over time, and optimal sustainable management of exhaustible, renewable resources (e.g., forests, fish and wildlife) over time. His focus on multiple values of natural resources helped provide the foundation for the "multiple use doctrine" followed to this day by the U.S. Forest Service and other federal and state natural resource management agencies (e.g., U.S. Bureau of Land Management, U.S. Army Corps of Engineers).

\section{National Parks and Natural Resource Conservation and Preservation}

Another major, ground-breaking development in the American conservation movement occurred on March 1, 1872 when President Ulysses S. Grant signed into law the Congressional bill establishing the world's first national park, Yellowstone National Park, which stretches across parts of Montana, Wyoming, and Idaho. The national park concept, however, has earlier roots back to June 30, 1864 when President Abraham Lincoln signed legislation providing federal protection to the Yosemite Valley and the Mariposa Grove of Giant Sequoias in California for "public use, resort, and recreation." 
Yellowstone National Park was established primarily to protect the unique landscape and geologic features of the area including natural geysers (e.g., what is now known as "Old Faithful" geyser). The second national park was established on September 25, 1890 when President Benjamin Harrison signed the Congressional bill establishing Sequoia National Park in California. Sequoia National Park was the first national park established primarily to protect living, biological resources - the gigantic Sequoia trees (Sequoiadendron giganteum).

President Harrison also signed legislation establishing Yosemite National Park as the nation's third national park on October 1, 1890. When Sequoia and Yosemite National Parks were established in 1890, a national park service with park rangers who manage the parks did not yet exist. Thus, management of these two national parks, along with Yellowstone National Park, was assigned to the U.S. Army. An African American company of soldiers under the command of Captain Charles Young, who was a commissioned African American U.S. Army Officer (in fact, the only one of such at the time), was given the task of protecting and managing the natural resources in Sequoia and Yosemite National Parks.

It took until the early 1900 s before significantly more national parks were established through many "grassroots" efforts and the political will and action at the national level and in Washington, D.C. led by President Theodore Roosevelt. Roosevelt's interests in and commitment to protecting public lands in the western U.S. as national parks and monuments were inspired by a buffalo hunting trip to North Dakota in 1883, a family vacation to Yellowstone National Park in 1890, a later visit and tour of Yellowstone National Park with well-known at the time naturalist John Burroughs, and a particularly impactful three-day camping trip with John Muir in Yosemite Valley in 1903. Muir took full advantage of this unprecedented time alone with the President in nature to share his philosophy and passion for protecting the natural wonders and "cathedrals" of America. President Roosevelt's contributions to the conservation movement included signing legislation creating five national parks and establishing 51 bird reserves, four game reserves, and 150 national forests (working with Gifford Pinchot). In 1906, he also signed into law the U.S. Antiquities Act which he used extensively, and not without controversy, to proclaim 18 new national monuments.

The establishment of national parks, national monuments, and other units of the national park system has had much influence on natural resource and environmental economics. For example, origins of the travel cost method can be traced back to a letter written by Harold Hotelling to the National Park Service suggesting such a method for estimating the demand for national park visits. The letter was in response to an appeal initiated by the Director of the National Park Service for ideas on how to value national park services (Hotelling, 1947). The Director was interested in, as are many government administrators 
to this day, obtaining data about the economic benefits of national parks in order to help justify federal budget expenditures (costs) on national parks (Hanemann, 1992).

With respect to natural resource use, national parks and the national park system also moved away from the "multiple-use doctrine" advocated by Gifford Pinchot and followed by the U.S. Forest Service to focusing more on non-consumptive recreational uses of natural resources. One of the earliest advocates of preserving natural resources in the U.S. for their aesthetic and scenic values was John Muir. The "preservationist" approach/environmental ethic in the tradition of John Muir and the "conservationist" approach/environmental ethic in the tradition of Gifford Pinchot came to philosophical blows and practical management conflicts in the Hetch Hetchy Valley (California) preservation debate in the early 1900s. In the end, the practical needs of the City of San Francisco for municipal water supplies won the day and resulted in the building of a dam and reservoir in the Hetch Hetchy Valley resulting in the flooding and loss of what John Muir called the second Yosemite Valley actually the valley is still there, it is just under a lot of water and technically could be restored someday if the dam were to be removed (something Hetch Hetchy Valley advocates have pushed for in recent years).

\section{Development of Formal Economic Models of Optimum Resource Use}

The conservationist approach to natural resource management is consistent with the concept of economic conservation pioneered by Ciriacy-Wantrup (1968) in his classic book Resource Conservation: Economics and Policies. More specifically, he defined the optimal state of conservation as the rate of resource use that would maximize the present value of net revenues over time (Ciriacy-Wantrup, 1968; Brown et al., 2016). This general rule is the basis for the dynamic optimization approach for analyzing economically optimal natural resource use and management - which is a core component of natural resource economics teaching programs.

In the case of exhaustible, non-renewable resources, the concept of an optimal time path of consumption can be traced back further to Harold Hotelling. Hotelling was a mathematician turned economist who was a professor at Stanford University, Columbia University, and the University of North Carolina-Chapel Hill until he retired in 1966. He was one of the early pioneers in the fields of mathematical economics and econometrics (Arrow and Lehman, 2012). Heal (2007) also credits Hotelling as "in many ways, the founder of analytical resource and environmental economics." In his seminal 1931 paper on the economics of exhaustible resources, Hotelling formulated what is now known as Hotelling's Rule which states that the optimal price path and extraction rate for exhaustible resources occurs where the resource output 
price is increasing at the market interest rate. Such a price path maximizes net returns from extraction over time (Hotelling, 1931; Heal, 2007).

In the case of renewable resources, theory and methods for optimal resources use and management is rooted in forestry and fisheries management. Optimal management of forests and fisheries introduced the concept of "sustainable use" into natural resource and environmental economics. Because trees and fish can reproduce themselves through biological growth, it is possible to harvest a given level of these resources on a sustainable basis, year after year. As with non-renewable resources, the optimal harvest of renewable resources from an economic perspective is the rate of harvest that maximizes net returns over time. Early pioneering contributors to the economic theory of fisheries economics, an example of common pool resources, include H. Scott Gordon, Anthony Scott, and James Crutchfield (Gordon, 1954; Scott, 1955; Crutchfield, 1961; Brown et al., 2016). Faustmann (1849) and Hartman (1976) are credited with the development of forestry economics (Brazee, 2001).

The development of natural resource and environmental economics over time has also been heavily influenced by the need to assess and provide practical solutions to the use and allocation of water. Griffin (2012) provides a comprehensive review of the "origins and ideals" of water resource economics, including major contributors to theory and techniques especially during what he terms the "classic era" of water resource economics (1945-1969). In the U.S., he traces the development of water resource economics back to the early 1900s when federal legislation was passed to deal with national problems and needs related to flood control, navigation, and irrigation (especially in the arid Western U.S.). ${ }^{5}$ This early legislation resulted in the system of federal water management projects we see today throughout the U.S., particularly dams and reservoir systems.

Eventually, outdoor recreation became a formally recognized benefit of federal water projects which resulted in the development of economic theory and techniques for estimating use values of water-based outdoor recreation in particular, revealed preference techniques such as the travel cost method. Today, in addition to use values, passive use or non-use values are recognized as important benefits of water resources contributing, for example, to preservation of critical wildlife habitat (e.g., wetlands) and existence values of wildlife species that depend on this habitat. The need to value passive use or non-use values for inclusion in policy and project assessment (e.g., benefit-cost analysis) spurred on development of stated preference theory and techniques for measuring these values such as contingent valuation and choice experiments (Banzhaf, 2010; Griffin, 2012).

The "conservationist" philosophy and concept of economic conservation historically (and in many ways up to today) tends to focus on consumptive use values of natural resources and the environment (e.g., think optimal 
extraction rate of crude oil from a privately-owned well, optimal harvest of trees from a privately-owned forest, optimal commercial harvest rate of fish from a common-property fishery). As mentioned above, the conservationist philosophy and arguments of Gifford Pinchot and allies prevailed over the preservationist philosophy and arguments of John Muir in the fight to save the Hetch Hetchy Valley in the Sierra Nevada Mountains of California from flooding for a water reservoir. In his arguments for preserving the valley in its natural, unflooded state, John Muir emphasized non-consumptive use and non-use of the valley. For example, he foresaw that Yosemite Valley would eventually become crowded with recreational users and argued that the nearby Hetch Hetchy Valley would provide a needed, and near equal, substitute site for hiking, camping, and other forms of non-consumption outdoor recreational activities (even though John Muir and Teddy Roosevelt were generally allies in the National Park movement, Muir did not share Roosevelt's passion for consumptive outdoor recreational activities such as hunting).

Muir also emphasized the need to preserve the rare aesthetic beauty of the Hetch Hetchy Valley in its natural form. John Muir's writings in which he reflects upon the natural beauty and majesty of the Sierra Nevada Mountains suggest that he also recognized intrinsic and non-use (or passive use) values of natural resources and the environment. He, himself, certainly spent time off-site (e.g., at home) thinking about and reflecting on the beauty and majesty of natural environments, contributing perhaps to his own enjoyment from what natural resource and environmental economists now call existence value. His essays describing the natural wonders of the Sierra Nevada Mountains to readers in the populated (and crowded) cities of the East Coast may have also contributed to these readers holding existence values for places such as the Yosemite and Hetch Hetchy Valleys. Formal theoretical recognition by economists of the existence of existence value would come much later as described below.

\section{THE "ENVIRONMENTAL MOVEMENT" AND ENVIRONMENTAL ECONOMICS}

The conservation movement in the U.S. of the late 19th century and early 20th century eventually developed and expanded into a broader environmental movement in the 1960s and 1970s. ${ }^{6}$ The need for a broad environmental movement was, in part, catalyzed by the Cuyahoga River catching fire in 1969 due to uncontrolled dumping of industrial waste. ${ }^{7}$ In addition, I recall during my undergraduate college days in the 1970s, there was also much concern expressed inside and outside of the classroom about the human "population explosion" leading to growing resource scarcity and limits to economic growth and social well-being. A very influential Club of Rome report entitled, The 
Limits to Growth (Meadows et al., 1972) contributed to these Malthusian type concerns. As every student of natural resource and environmental economics knows (or should know), concerns over human population and resource scarcity leading to a "day of reckoning" where human population growth outstrips natural resource availability with dire consequences for humanity and society dates back at least to Thomas Malthus and what we now call the "Malthusian Doctrine" discussed earlier in this chapter.

The Limits to Growth report and other ensuing related papers and discussion spurred economists in the 1970s to think more deeply and broadly about the values of scarce natural resources. At that time and before, economists were familiar with the relationships between natural resource scarcity and economic rent introduced by David Ricardo, who was another classical economist living and writing about the same time and place as Thomas Malthus (e.g., England in the 18th century and early 19th century). Ricardo theorized that scarce agricultural land in England should command a surplus economic value or rent we now refer to as "land rent" - and the scarcer, the higher should be the land rent associated with agricultural production (Ricardo, 1817). ${ }^{8}$

In modern neoclassical economic theory, land rent is akin to the concept of producer surplus which is used to measure the net benefits to firms of producing goods and services. The concept of consumer surplus is used to measure the net benefits to consumers of consuming goods and services. Consumer surplus, like producer surplus (e.g., land rent) is affected by resource scarcity. For example, ceteris paribus, we would expect the net benefits (consumer surplus) a person receives from hiking at a highly unique and beautiful natural area (e.g., Yosemite Valley or Grand Canyon) to be higher as compared to hiking at a common, non-unique site such as a local park (with perhaps the exception of Central Park in New York City and the like).

In addition to consumer surplus values arising from active uses of natural resources, natural resource and environmental economists nowadays recognize that people can derive consumer surplus values even when not actively using a natural resource - what we now call non-use values. The clearest example of a non-use value is existence value defined as the value (consumer surplus) a person places merely thinking about and reflecting on the existence of a natural resource independent of any type of actual use. The more formal recognition and definition of existence value is usually attributed to the classic article written by John Krutilla entitled "Conservation reconsidered" (Krutilla, 1967), although the genesis of the idea can also be traced back to Ciriacy-Wantrup's Resource Conservation book (Brown et al., 2016). Later theoretical developments led to more formal definitions of use and non-use values and associated theoretically appropriate welfare measures (e.g., Hicksian compensating and equivalent surplus) based on applied welfare economics (e.g., see Randall and Stoll, 1980; Hanemann, 1984; and Chapter 3 in 
this book). These theoretical developments provided the theoretical grounding for the parallel development of nonmarket valuation techniques for measuring use and non-use values.

\section{Recognition of Market Failures}

In addition to a recognition of the broad values of natural resources and the environment to include both use and non-use values, the environmental movement of the 1960s and 1970s ushered in a new era of applying economic theory to the solution of negative externality problems such as air and water pollution. Rachel Carson's famous book, Silent Spring, was a major contributor to popular recognition of externality problems, both within and outside of academia. In this book, in a very readable and relatable way (often tough for scientists to do), Carson showed how DDT spraying for mosquitos led to the negative externality and unintended consequence of harming bird eggs and reproduction which would eventually lead to spring without the singing of birds, or a silent spring (Carson, 1962).

The DDT negative externality problem described by Carson in Silent Spring is a type of "market failure" or "market inefficiency" defined as the failure or inability of private markets to satisfy the conditions necessary and sufficient for a competitive market equilibrium to be Pareto efficient. Toxic chemical contamination of the environment, such as from DDT, is a "public bad." In such cases, the private market results in "too much" of the public bad from a Pareto efficiency (economic efficiency) standpoint. Market failure also can occur in the case of positive externalities such as "public goods." Examples of public goods include clean water and clean air. In general, private markets will provide "too little" of the public good from a Pareto efficiency (economic efficiency) standpoint. As pointed out by Samuelson in his seminal article on public goods, in the case of public goods that are nonrival in consumption (e.g., everyone can consume the same amount, of say, clean air in a day), Pareto efficiency involves vertical summation of demand curves - which is not easily done in practice due to the "free rider" problem and associated difficulty in measuring consumers' true willingness-to-pay for public goods (Samuelson, 1954).

In the 1970s and beyond, the application of economics to environmental policy-making such as developing and implementing market-like solutions to air and water pollution problems (e.g., tradable pollution permits) proliferated. The first Earth Day, which occurred on April 22, 1970, has been credited with raising national environmental awareness and helping to launch federal environmental regulation. Earth Day was one of several major environmental events in 1970 including passage of the Clean Air Act and the National Environmental Policy Act (NEPA). In addition to the Clean Air Act, the 1972 
Federal Water Pollution Control Act (which was renamed the Clean Water Act with its 1977 amendments), the Endangered Species Act, the Safe Drinking Water Act, and several other major pieces of legislation were passed in the 1970s. These policies helped to stimulate an explosion of research in the area of environmental and resource economics (Freeman, 2002; Pearce, 2002; Fouquet, 2019).

\section{Correcting for Market Failures}

When teaching about environmental economics and policy, a usual starting point is introducing students to the neoclassical economist Arthur Pigou and the concepts of Pigouvian taxes and subsidies as a means for correcting negative externalities (Pigou, 1920; Pearce, 2002). Pigouvian taxes, for example, are the theoretical basis for current proposals to use carbon taxes to reduce carbon emissions, say by industrial factories and power plants. Allen Kneese, an environmental economist at Resources for the Future, was instrumental in the application of Pigouvian pricing in environmental economics (Banzhaf, 2020). Kneese first laid out the notion that later became known as "green taxes" could be used to achieve the efficient amount of pollution cost effectively relative to command-and-control policy.

Ronald Coase offered an alternative approach (now known as the "Coase Theorem") to solving externality problems based on voluntary transactions whereby the party generating the externality and the party affected by the externality negotiate the externality away (Coase, 1960). For example, given all the right conditions, the Coase Theorem suggests that a downstream farmer whose use of river water is impaired by nutrient run-off from an upstream farmer, could pay the upstream farmer to modify agricultural operations on the upstream farm to reduce nutrient run-off. The end theoretical result of applying the Coase Theorem is a Pareto-efficient level of negative externality (e.g., pollution) abatement, as with Pigouvian taxes and subsidies. The Coase Theorem is primarily applicable to externalities with only a few parties that are affected such that they can negotiate over internalizing the externality. However, most policy relevant externalities such as urban air pollution or pollution of interstate waterways involve thousands, if not millions of people, and hence the Coase Theorem does not provide a practical solution in these cases. ${ }^{9}$

Since the decade of the 1970s federal environmental regulation has moved away from rigid standards and become more incentive-based and flexible. Tom Crocker (1966) and Dales (1968) introduced the concept of tradeable pollution permits for air (Crocker) and water (Dales) pollution. Hahn (1989) reviews a number of these early efforts. The first large-scale implementation of tradeable pollution permits was with the Acid Rain Program in the 1990 Clean Air Act Amendments. This "grand experiment" in tradeable pollution permits 
has been credited with achieving more reductions in acid rain at lower cost than expected (Stavins, 1998). ${ }^{10}$

With respect to making efficient natural resource and environmental management and policy decisions, economists have long recognized that individual and group (societal) decisions do not occur in an institutional vacuum. In reality, institutions, especially property rights, heavily influence the economic outcomes of individual and group decisions affecting natural resources and the environment. This "institutional economics" school of thought has origins in natural resource and environmental economics in the field of "land economics" which focuses on "the economic relationships people have with others respecting land" (Barlowe, 1986, p. 3). Barlowe traces the origins of land economics back to a seminar on landed property taught by Richard Ely at the University of Wisconsin in 1892. Formal recognition of land economics as a separate field of economics, according to Barlowe, occurred in 1919 with the establishment of the Division of Land Economics in the U.S. Department of Agriculture (ibid.). Although some universities still offer stand-alone courses in land economics, in many applied economics departments, concepts from land and institutional economics are taught as components of broader natural resource and environmental economics.

For example, in my "Principles of Resource Economics" undergraduate course, I teach a section on institutions affecting natural resource use, allocation, and management focusing on property rights. Considering property rights and physical characteristics affecting production and consumption, natural and environmental resources can be grouped into four broad categories: (1) rival, exclusive; (2) rival, nonexclusive; (3) nonrival, exclusive; and (4) nonrival, nonexclusive. Rival, exclusive resources include pure private goods such as crude oil, natural gas, and other minerals. Nonrival, nonexclusive resources include pure public goods such as clean ambient air. Rival, nonexclusive resources include "open access" resources with res nullius property rights such as fish in international waters and minerals on Earth's moon.

Nonrival, exclusive resources include "common property" resources with res communis property rights such as public timber land in the U.S. managed by the U.S Forest Service (National Forests), public livestock grazing land in the U.S. managed by the U.S. Bureau of Land Management, and ocean fisheries controlled and managed by different countries within their 200-mile territorial limits (Bergstrom and Randall, 2016, Chapters 9 and 10). Probably every student who has taken a natural resource or environmental course at a college or university around the world has read or at least heard about the "tragedy of the commons." The tragedy of the commons, popularized by Garrett Hardin his classic 1968 Science article, refers to depletion and exhaustion of "open access" type resources with little or no property rights governing use. In the absence of property rights or other institutions (e.g., customs, 
commonly accepted "rules of the game"), there is an incentive for people to want to "capture" and consume a resource before somebody else does which can lead to a "free for all" and overexploitation of a resource from economic, environmental, and social (ethical) perspectives (e.g., the "triple bottom line").

One solution to open-access resource problems is to establish private property rights over the resource (e.g., privatize the resource) with the main idea being that private owners will have an economic incentive to use and manage the resource in a wise and efficient manner - for example, a farmer/landowner should have an economic incentive to follow "best practice" soil and water conservation farming techniques on the land. This "privatize the resource" approach is consistent with the Austrian economics school of thought which promotes the benefits of private property institutions and free markets, and Nobel laureate James Buchanan's "public choice theory" which questions whether imperfect, self-interested government officials operating in imperfect government institutions can do a better job of achieving Pareto-efficient outcomes as compared to imperfect, self-interested producers and consumers operating in imperfect private markets (Anderson, 1982; Randall, 1985).

In contrast, other economists in the tradition of land/institutional economics have argued that natural and environmental resources can (and perhaps should) be efficiently managed as "common property" resources if the common owners and users of the resource effectively cooperate together to achieve mutually beneficial ends such as conservation of soil and water resources (Bromley, 1982; Randall, 1985). For example, Nobel laureate Elinor Ostrom studied small communities around the world and found that social norms and other "grass root" institutional arrangements could prevent overexploitation and exhaustion of common property or common pool resources. Based on theoretical insight including from game theory and empirical observation, Ostrom developed eight fundamental design principles for stable use and management of common property or common pool natural resources including shared grazing land and fisheries (Ostrom, 1990, 2010).

Concern over natural resource depletion and environmental degradation has led to another school of thought in economics focusing on ecosystems and ecosystem goods and services - ecological economics. Pearce (2002) traces ecological economics back to Kenneth Boulding's classic "spaceship Earth" essay (Boulding, 1966). In this essay, Boulding described the Planet Earth as a "closed system" akin to a closed ecosystem subject to positive and negative feedback loops and cycles (e.g., chemical cycles). In a closed ecosystem or economy, for example, human-induced air and water pollution could cause a negative feedback loop affecting the health and integrity of ecosystems and their ability to provide ecosystem goods and service of value to people. Viewing coupled ecosystems and economies in the nature of closed economies suggests the need for a proper balance of natural capital inputs and 
environmental outputs (including pollution) in order to sustain both healthy ecosystems and economies. ${ }^{11}$

Pearce (2002) discusses the extent to which ecological economics is a "new paradigm" as compared to environmental economics based on neoclassical economic theory and models. As far as I know, very few economics and applied economics departments teach separate ecological economics courses. However, concepts emerging from or highlighted by ecological economics such as natural capital, materials balance, ecosystem services, and sustainable development are often incorporated into natural resource and environmental economics teaching and research programs.

\section{CONCLUDING REMARKS}

This chapter highlights the academic history and heritage of natural resource and environmental economics including key contributors and programs. The chapter integrates this history and heritage with the rise and development of the "conservation movement" and "environmental movement" in the United States. The story is told from the personal perspective and reflections of the author who began his own journey into the field and natural resource and environmental economics as an undergraduate student in the 1970s. The chapter serves two purposes for this book. First, I and my co-editor John Whitehead hope that this historical overview is useful as a teaching resource. In the classes we teach in natural resource and environmental economics, we have found that brief discussions of the history of economic thought stimulates students' interest in the textbook material, and helps them to better understand the material by reference to the original sources and reasons why particular theories, concepts, and methods came about. Second, this chapter provides context for the remainder of this book with respect to appreciating and passing on the rich heritage and modern content of natural resource and environmental economics to current and future students of the field.

\section{NOTES}

1. I gratefully acknowledge John Whitehead (the other co-editor of this book) and John Loomis for many very helpful comments and edits on this chapter. I am also indebted to many colleagues who graciously responded to my request on the Land \& Resource Economics Network listserve (RESECON) for input and references related to the historical development of natural resource and environmental economics.

2. I recall that during the 1970 s, Thoreau's Walden was one of the philosophical and practical "guidebooks" for "back-to-the-land"-type young people seeking a more simple, natural, and environmentally friendly lifestyle whose heritage has been passed on to modern-day rural and urban "homesteaders." 
3. One of the chapter authors of this book, Robert Johnston, is Research Professor and Director of The George Perkins Marsh Institute at Clark University in Worcester, MA. The Marsh Institute and the natural resource and environmental research it supports reflects the ongoing legacy of George P. Marsh.

4. The popular film by Ken Burnes, The National Parks: America's Best Idea, provides an excellent and interesting documentation of John Muir's nature philosophy as well as an overview of the conservation movement in the United States. I have used this film in a freshman seminar course at the University of Georgia designed to introduce students to conservation and resource management historical thought and practice.

5. The Reclamation Act of 1902 was passed in response to the demand for irrigation water by farmers in the Intermountain West region of the U.S. which led to the establishment of the Bureau of Reclamation, which built and manages large water development in this region including one of its first and most well-known projects, the Hoover Dam and Reservoir (Lake Mead Project). In addition to irrigation water, the project was built to provide flood control and hydroelectricity benefits. Today, outdoor recreation is also a major benefit of Lake Mead including the first and largest national recreation area in the U.S., Lake Mead National Recreation Area (https://www.nps.gov/lake/index.htm).

6. For exposition purposes, I have divided this chapter into sections on the "conservation movement" and natural resource economics and the later "environmental movement" and environmental economics. However, over time, both the conservation and environmental movements influenced developments in both the fields of natural resource economics and environmental economics. Also, even in my own thinking, it is often difficult to draw a clear line between the conservation and environmental movements and the fields of natural resource economics and environmental economics. That is, as I "pan out" to a broader "birds-eye view," the conservation movement, environmental movement, natural resource economics, and environmental economics tend to merge together into a more holistic and interconnected paradigm (which also includes ecological economics).

7. I am grateful to John Loomis for this additional insight on the origins of the environmental movement.

8. Johann Heinrich von Thünen, the name of another classical economist which should be familiar to students of natural resource and environmental economics, conceptualized scarcity rent as deriving from geographical location whereby land closest to the "city center" would command the highest economic surplus value (von Thünen, 1826).

9. My thanks to John Loomis for the reminder and addition of this practical limitation of Coase-type solutions to broad externality problems.

10. I appreciate John Whitehead's addition of this paragraph and other insights on the history of environmental policy and its relationships with environmental economics.

11. Pearce (2002) points out that such a "material balance" model of an economy was first formalized by Ayres and Kneese (1969).

\section{REFERENCES}

Albright, H.M. (1988), 'Great American Conservationists', in Conservators of Hope: The Horace M. Albright Conservation Lectures, Moscow, ID: University of 
Idaho Press in Cooperation with the Board of Regents of University of California, Berkeley.

Anderson, T.L. (1982), 'The new resource economics: Old ideas and new applications', American Journal of Agricultural Economics, 64 (5): 928-934.

Arrow, K.J. and E.L. Lehmann (2012), 'Harold Hotelling', in Selected Works of EL Lehmann, Boston, MA: Springer, pp. 903-915.

Ayres, R., and A. Kneese (1969), 'Production, consumption, and externalities', American Economic Review, 59 (3): 282-297.

Banzhaf, H.S. (2010), 'Consumer surplus with apology: A historical perspective on nonmarket valuation and recreation demand', Annual Review of Resource Economics, 2: 18.1-18.25.

Banzhaf, H.S. (2020), 'A history of pricing pollution (or, why everything you thought you knew about it is wrong and Pigouvian taxes are not necessarily Pigouvian)', unpublished manuscript, June.

Barlowe, R. (1986), Land Resource Economics, Fourth Edition, Englewood Cliffs, NJ: Prentice-Hall.

Bentham, J. (1776), A Fragment on Government: Being an Examination of What is Delivered, on the Subject of Government in General in the Introduction to Sir William Blackstone's Commentaries: With a Preface, in Which is Given a Critique of the Work at Large, London: Printed for T. Payne, P. Elmsly and E. Brooke.

Bentham, J. (1789), An Introduction to the Principles of Morals and Legislation. Printed in the Year 1780, and Now First Published. By Jeremy Bentham. London: Printed for T. Payne and Son.

Bergstrom, J.C. and A. Randall (2016), Resource Economics: An Economic Approach to Natural Resource and Environmental Policy, Cheltenham, UK and Northampton, MA, USA: Edward Elgar Publishing.

Boulding, K. (1966), 'The economics of the coming spaceship Earth', in H. Jarett (ed.), Environmental Quality in a Growing Economy, Baltimore: Johns Hopkins University Press, pp. 3-14.

Brazee, R. (2001), 'The Faustmann formula: Fundamental to forest economics 150 years after publication', Forest Science, 47 (4): 441-442.

Bromley, D.W. (1982), 'Land and water problems: An institutional perspective', American Journal of Agricultural Economics, 64 (5): 834-844.

Brown, G.M., V.K. Smith, G.R. Munro and R. Bishop (2016), 'Early pioneers in natural resource economics', Annual Review of Resource Economics, 8: 25-42.

Carson, R. (1962), Silent Spring, Boston, MA: Houghton Mifflin.

Ciriacy-Wantrup S.V. (1952), Resource Conservation: Economics and Policies, Oakland, CA: University of California Press.

Coase, R. (1960), 'The problem of social cost', Journal of Law and Economics, 3 (1): $1-44$.

Crocker, Thomas D. (1966), 'The structuring of atmospheric pollution control systems', in H. Wolozin (ed.), The Economics of Air Pollution, New York: Norton, pp. 61-86.

Crutchfield, J.A. (1961), 'An economic evaluation of alternative methods of fishery regulations', Journal of Law and Economics, 4: 131-43.

Dales, J. (1968), Pollution, Property and Prices, Toronto: University Press.

Emerson, R.W. (1836), Nature, Boston, MA: James Munroe.

Faustmann, M. (1849), 'On the determination of the value which forestland and immature stands pose for forestry', Reprinted in the Journal of Forest Economics, 1: 7-44 (1995). 
Fouquet, R. (2019), 'Introduction', in R. Fouquet (ed.), Handbook on Green Growth, Cheltenham, UK and Northampton, MA, USA: Edward Elgar Publishing.

Freeman, A.M. (2002), 'Environmental policy since Earth Day I: What have we gained?', Journal of Economic Perspectives, 16 (1): 125-146.

Gordon H.S. (1954), 'The economic theory of a common property resource: The fishery', Journal of Political Economy, 62: 124-142.

Griffin, R.C. (2012), 'The origins and ideals of water resource economics in the United States', Annual Review of Resource Economics, 4 (1): 353-377.

Groom, B. and M. Talevi (2020), 'How does economics address the environment?', Chapter 14, in K. Deane and E.V. Waeyenberge (eds), Recharting the History of Economic Thought, London, UK: Red Globe Press, pp. 247-268.

Hahn, R.W. (1989), 'Economic prescriptions for environmental problems: How the patient followed the doctor's orders', Journal of Economic Perspectives, 3 (2): 95-114.

Hanemann, W.M. (1984), 'Welfare evaluations in contingent valuation experiments with discrete responses', American Journal of Agricultural Economics, 66 (3): 332-341.

Hanemann, W. Michael (1992), 'Preface', in S. Navrud (ed.), Pricing the European Environment, New York: Oxford University Press, pp. 9-14.

Hardin, G. (1968), 'The tragedy of the commons', Science, 162 (3859): 1243-1248.

Hartman, R. (1976), 'The harvesting decision when a standing forest has value', Economic Inquiry, 14 (1): 52-58.

Heal, G. (2007), 'A celebration of environmental and resource economics', Review of Environmental Economics and Policy, 1 (1): 7-25.

Hotelling, H. (1931), 'The economics of exhaustible resources', Journal of Political Economy, 39 (2): 137-175.

Hotelling, H. (1947), Letter to the National Park Service, Published in Prewitt (1949), The Economics of Public Recreation: The Prewitt Report, Washington, D.C.: U.S. Department of the Interior.

Kling, C.L., K. Segerson and J.F. Shogren (2010), 'Environmental economics: How agricultural economists helped advance the field', American Journal of Agricultural Economics, 92 (2): 487-505.

Krutilla, J.V. (1967), 'Conservation reconsidered', American Economic Review, 57 (4): 777-786.

Lichtenberg, E., J. Shortle, J. Wilen and D. Zilberman (2010), 'Natural resource economics and conservation: Contributions of agricultural economics and agricultural economists', American Journal of Agricultural Economics, 92 (2): 469-486.

Malthus, T.R. (1798), 'An essay on the principle of population', in Oxfords World Classics reprints.

Marsh, G.P. (1864), Man and Nature: Physical Geography as Modified by Human Action, New York, NY: Charles Scribner.

Meadows, D.H., D.L. Meadows, J. Randers and W.W. Behrens III (1972), The Limits to Growth: A Report for the Club of Rome's Project on the Predicament of Mankind, New York: Universe Books.

Muir, J. (1894), The Mountains of California, New York: The Century Company.

Muir, J. (1911), My First Summer in the Sierra, Boston: Houghton Mifflin Company.

Ostrom, E. (1990), Governing the Commons: The Evolution of Institutions for Collective Action, Cambridge, UK: Cambridge University Press.

Ostrom, E. (2010), 'Beyond markets and states: Polycentric governance of complex economic systems', American Economic Review, 100 (3): 1-33. 
Pearce, D. (2002), 'An intellectual history of environmental economics', Annual Review of Energy and the Environment, 27 (1): 57-81.

Pigou, A.C. (1920), The Economics of Welfare, London: Palgrave Macmillan.

Pinchot, G. (1910), The Fight for Conservation, New York, NY: Doubleday, Page \& Company.

Randall, A. (1985), 'Methodology, ideology, and the economics of policy: Why resource economists disagree', American Journal of Agricultural Economics, 67 (5): 1022-1029.

Randall, A. and J.R. Stoll (1980), 'Consumer's surplus in commodity space', American Economic Review, 71 (3): 449-457.

Ricardo, David (1817), On the Principles of Political Economy and Taxation, London: John Murray, Albemarle Street.

Samuelson, P.A. (1954), 'The pure theory of public expenditure', Review of Economics and Statistics, 36 (4): 387-389.

Sandmo, A. (2015), 'The early history of environmental economics', Review of Environmental Economics and Policy, 9 (1): 43-63.

Scott, A.D. (1955), 'The fishery: The objectives of sole ownership', Journal of Political Economy, 63 (2): 116-124.

Spash, C. (1999), 'The development of environmental thinking in economics', Environmental Values, 8 (4): 413-435.

Stavins, R.N. (1998), 'What can we learn from the grand policy experiment? Lessons from SO2 allowance trading', Journal of Economic Perspectives, 12 (3): 69-88.

Thoreau, H.D. (1854), Walden: Life in the Woods, Boston, MA: Ticknor \& Fields.

Thoreau, H.D. (1862), 'Walking', The Atlantic Magazine, May.

Viitala, E.J. (2013), 'The discovery of the Faustmann formula in natural resource economics', History of Political Economy, 45 (3): 523-548.

von Thünen, Johann Heinrich (1826), Der isolierte Staat (The Isolated State), Hamburg: Wirtschaft \& Finan.

Yeoman, B. (2014), 'Why the passenger pigeon went extinct', Audubon Magazine, May-June. 